\title{
Investigating Students' Barriers in Young Adult Literature
}

\author{
Kiki Rizki Amelia ${ }^{1 *}$ and Fitri Novia ${ }^{2}$ \\ ${ }^{1}$ English Language Education Study Program at FKIP Islamic University of Ogan Komering Ilir Kayuagung, South \\ Sumatera 30618, Indonesia \\ ${ }^{2}$ English Language Education Study Program at FKIP Islamic University of Ogan Komering Ilir Kayuagung, South \\ Sumatera 30618, Indonesia \\ *Corresponding author. Email: kikirizkiamelia333@gmail.com
}

\begin{abstract}
Young adult literature is authentic material that can be used with junior high school students. Nonetheless, students may find it difficult to read young adult literature as a source of information. The purpose of this research was to find out students' difficulties in reading young adult literature. The method of this study was descriptive qualitative. The sample consisted of 40 students of SMP N 1 Inderalaya Selatan. In this study, a reading test in the form of a multiple choice with 30 questions was used as an instrument. Based on data analysis, students struggled to answer questions on the main idea, supporting details, inference, cause/effect, and vocabulary. As a result, the findings of this study may be helpful to policymakers in improving the reading experience of learners.
\end{abstract}

Keywords: investigating, students' barriers, young adult literature

\section{INTRODUCTION}

Reading is an important ability to learn in order to gain access to information and knowledge. Reading allows students to express their thoughts and ideas both orally and in writing. Reading can be defined as a process of extracting meaning from printed words or linguistic symbols in written material. The reader must understand what she or he is reading in order to grasp the text's intended purpose. To comprehend the meaning, the reader uses both his or her linguistic skills and a background of global knowledge. To improve students' abilities, the Indonesian government supports EFL in the classroom by making English classes a mandatory subject for junior and senior high school students [1].

Moreover, the teacher should select relevant material to enhance students' reading comprehension. Hence, the choice of the materials used in teaching and learning process is substantial. Literature is one of promising candidates can be used in studying English. Literature is divided into three. There are: Children Literature, Young Adult Literature, and Adult Literature. Young Adult Literature (YAL) is appropriate for the junior and senior high school students.

Young Adult Literature (YAL) is one of literature work that can be used as authentic material for reading. YAL can be defined as works that include a teen protagonist or teen protagonists and deal with topics that teens can relate to [2]. YAL is a type of creative endeavour that has the potential to develop enjoyment, empathy, creativity, and linguistic skills [3]. Young adult literature has a narrative style that is contemporary and appealing to young adults who are meaning makers, interested and engaged with emotional topics like family issues, identity construction, friendships, first love, making future decisions, and many others that increase students' motivation to read, share common problems, and learn teenage language [4].

In addition, YAL literature can be found in children's sections, popular adult texts areas, and mixed in with traditional canon sections in libraries and bookstores. YAL is being used to its full potential to assist students locate characters who are similar to them as well as characters who will help them better relate to others [5]. Students can learn more about themselves and the world around them by reading young adult literature [6].

The use of young adult literature in the classroom allows students to read and write on a variety of topics [7]. YAL can help to promote reading in the classroom and perhaps establish a connection to the classics. YAL can help to promote reading in the classroom and perhaps establish a connection to the classics [8]. Reading stories is an efficient way to learn grammar structures, syntax, new vocabulary, improve 
oral/written competencies, and therefore improve one's capacity to communicate effectively and successfully [9]. By using Young Adult Literature, teenagers can be inspired and motivated by reading, it promotes language acquisition by providing new context for vocabulary and grammar structures, it assists students in better understanding the meaning of a text, it fosters cultural awareness and imagination, as well as the ability to respond in a more critical and personal manner [10].

Unfortunately, Young Adult Literature continues to be neglected as a teaching reading resource. Despite the potential advantages of introducing YAL into the curriculum, teachers are still reluctant to use YAL in the classroom [11]. Many high school teachers avoid teaching Young Adult Literature in favour of classics, which refers to novels that have traditionally been taught in English classrooms and are appreciated for their timeless value, in order to instil in students a love for reading "real" literature [2]. Many EFL teachers are hesitant to include literature in their courses because they dislike it or are self-conscious about their lack of expertise in the field [10]. As middle-school teachers, we understand how difficult it is to keep teenagers engaged in their reading and encourage them to respond [12].

When it comes to bringing more young adult literature into the classroom, there are still some obstacles to overcome. Young adult literature, both fiction and nonfiction, provides a platform for both adolescents and their teachers to engage the social contradictions and complexities that are a part of their daily lives [13]. Students are rarely allowed a say in what literature they study in class; instead, teachers assign classic and canonical works without student involvement because the curriculum requires it, resulting in students losing interest in their reading [14].

Many young people still have limited knowledge of what they can access and little control over the books they are expected to read [15]. Many high school readers have not gained the skills essential to comprehend the classic works of literature offered in secondary English classes since they are not regular readers [8]. While students are expected to read, they do not always complete the work, even when it is given to them. It was noticed that students continued to study little textbook and literature material at school or at home, which is consistent with teacher observations that many students will not read literature material [16]. YAL was used by educators who wanted to help struggling readers. Fluency, vocabulary, understanding, and motivation were the primary concerns they discovered among struggling readers during their investigation [17].

Based on explanation above, the goal of this study was to find out what obstacles students face when reading young adult literature.

\section{METHOD}

This study used a descriptive qualitative research method. Multiple choice about reading narrative text was used to collect the data. Percentage was used to analyze the data. The sample consisted of 40 students of SMP N 1 Inderalaya Selatan. The instrument applied in this study was a reading test in the form of a multiple choice with 30 questions. Percentage was used to analyse the data.

\section{RESULT AND DISCUSSION}

Based on the analysis of the data, it was found that there were $59.5 \%$ of students who could answer questions about the main idea, $32.81 \%$ of students who could answer questions about the supporting detail indicator, $51 \%$ of students who could answer questions about the inference indicator, $22,5 \%$ of students who could answer questions about the cause/effect indicator, and $25 \%$ of students who could answer questions about the vocabulary indicator.

As a result, students struggled to understand young adult literature by answering questions about the main idea, supporting details, inference, cause/effect, and vocabulary. Due to the fact, the students were lack of vocabulary when they read about young adult literature, therefore, it led them difficult to understand about main idea, inference and cause/effect indicators from the text. Beside that, the students also seldom to read inside or outside classroom since they had low motivation to read textbook material such as young adult literature. It was supported that many pupils avoid reading altogether. Some of the difficulty in engaging pupils in their academic readings derives from the reading material itself [16].

In addition, students' interest in reading is influenced by motivation and creativity. Providing students with access to the titles of young adult literature that they enjoy and allowing them to choose topics, participate in discussions, and express their thoughts in a variety of ways can help accelerate them to read. One strategy to better understand students' reading motivation is to invite them to complete young adult books. Another technique to learn about a student's preferences is to have them fill out an interest inventory [12].

\section{CONCLUSION}

The result show that students struggled with main idea, supporting information, inference, cause/effect, and vocabulary issues. It occurred because students were lack of vocabulary when reading young adult literature, so that they got difficult to comprehend the text's main idea, inference, and cause/effect clues. Students also had low motivation to read authentic material such as young adult literature. As a result, the findings of this study could support policymakers in improving learners' reading experiences. Allowing students to choose topics, participate in discussions, and express their opinions in a number of ways might help them speed up their reading.

\section{REFERENCES}

[1] I. F. Wahyuni, "The assessment of Indonesian EFL 
students' reading comprehension ability using Reading Evaluation and Decoding System (READS)," in UAD TEFL International Conference, 2021, vol. 2, pp. 240-245, doi: 10.12928/utic.v2.5766.2019.

[2] D. Chakrabarty, "The Purpose of Teaching Young Adult Literature in Secondary Education: Focus on Poverty, Gender and Sexuality," Int. J. Educ. Lang. Relig., vol. 2, no. 2, 2020, doi: 10.35308/ijelr.v2i2.2366.

[3] L. C. Ee, "Engaging Students in Extensive Reading:," in Proceedings of the Fourth International Seminar onEnglish Language and Teaching (ISELT-4), 2016, pp. 48-52, doi: 10.20713/celes.47.0_245.

[4] M. Ayan, "Teaching Young Adult Literature: Catcher in the Rye As a Language Maker and Breaker," PEOPLE Int. J. Soc. Sci., vol. 3, no. 2, pp. 2175-2190, 2017, doi: 10.20319/pijss.2017.32.21752190.

[5] L. Mohler, "The Use of Diverse Young Adult Literature in High School Classrooms," 2019, [Online].

Available: https://digitalcommons.olivet.edu/engl_stsc/5.

[6] A. Hays, "Using Young Adult (YA) Literature in a Classroom: How Does YA Literature Impact Writing Literacies," Study Scrut. Res. Young Adult Lit., vol. 2, no. 1, pp. 53-86, 2016, doi: 10.15763/issn.2376-5275.2016.2.1.53-86.

[7] K. Toscano, "Using Young Adult Literature to Increase Student Success and Teach Multiculturalism," 2012, [Online]. Available: https://fisherpub.sjfc.edu/education_ETD_masters/ 231.

[8] K. R. Conner, "Building Bridges: Connecting to the Classics with Young Adult Literature," 2019, [Online]. Available: https://digitalcommons.gardnerwebb.edu/education_et.

[9] M. Pulimeno, P. Piscitelli, and S. Colazzo, "Children's literature to promote students' global development and wellbeing," Heal. Promot. Perspect., vol. 10, no. 1, pp. 13-23, 2020, doi: 10.15171/hpp.2020.05.

[10] L. Xaranzana and G. Manchado, "A taste of YA Introducing young adult literature in the EFL classroom." Univerrsitat De Les Illes Balears, 2018.

[11] H. "Cody" Miller, K. Colantonio-Yurko, and S. Boehm, "Confronting Concerns, Navigating Politics: Teaching Young Adult Literature in High School English Departments," English Leadersh. Q., vol. 42, no. 4, pp. 11-15, 2020, [Online]. Available:

https://login.proxy.lib.fsu.edu/login?url=http://sear ch.ebscohost.com/login.aspx?direct=true $\& \mathrm{db}=$ eue $\& \mathrm{AN}=143242543 \&$ site $=$ eds-live $\&$ scope $=$ site.

[12] M. McLaughlin and A. Gibb-Lucas, "Responding to Young Adult Literature: A Motivational Perspective," Voices from Middle, vol. 23, no. 4, pp. 78-83, 2016

[13] C. Holmes, "Teaching for Global Citizenship with Young Adult Literature in the Social Studies," Educ. Considerations, vol. 45, no. 1, 2019, doi: 10.4148/0146-9282.2166.

[14] A. Sell, "Bridgewater College BC Digital Commons To Read or Not To Read: Navigating Young Adult Literature in the Classroom in the Age of Trigger Warnings and Banned Books To Read or Not To Read: Navigating Young Adult Literature in the Classroom in the Age of Tr,' Honor. Proj. 61., 2021, [Online]. Available: https://digitalcommons.bridgewater.edu/honors_pr ojects/61.

[15] E. Arizpe, "Reading Changes: Adolescents, Young Adult Literature, and Literacy Practices in Mexico," J. Child. Lit., vol. 41, no. 1, p. 75, 2015.

[16] K. L. E. Wheaton, "Dickens and 'Divergent ': Engaging Students Through Use of Young Adult Literature as Supplemental Texts," Student Res. Submissions, vol. 136, 2015, [Online]. Available: https://scholar.umw.edu/student_research/136.

[17] K. Rybakova, A. Piotrowski, and E. Harper, "Teaching Controversial Young Adult Literature with the Common Core," Wisconsin English J., vol. 55, no. 1, pp. 37-45, 2013. 